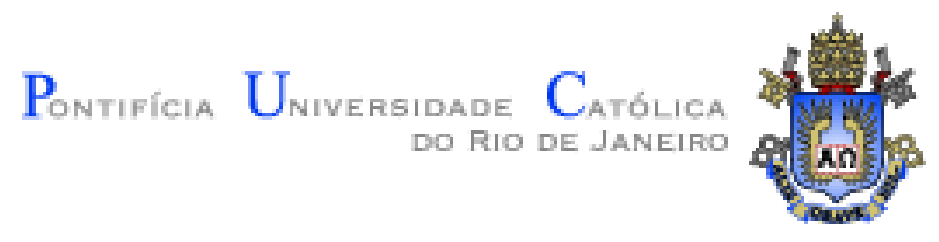

Caio Waisman

\title{
The effects of exposure to hyperinflation on occupational choice
}

Thesis presented to the Programa de Pós-Graduação em Economia of the Departamento de Economia , PUC-Rio as partial fulfillment of the requirements for the degree of Mestre em Economia

Adviser : $\quad$ Prof. Eduardo Zilberman

Co-Adviser: Prof. João Manoel Pinho de Mello 


\section{Caio Waisman}

\section{The effects of exposure to hyperinflation on occupational choice}

Thesis presented to the Programa de pós-graduação em Economia of the Departamento de Economia , PUC-Rio as partial fulfillment of the requirements for the degree of Mestre em Economia. Approved by the following commission:

Prof. Eduardo Zilberman

Adviser

Departmento de Economia - PUC-Rio

Prof. João Manoel Pinho de Mello

Co-Adviser

Departmento de Economia - PUC-Rio

Prof. Gustavo Maurício Gonzaga

PUC-Rio

Prof. Miguel Nathan Foguel

IPEA

Prof. Monica Herz

Dean of Graduate Studies of the Centro de Ciências Sociais

PUC-Rio

Rio de Janeiro - March 18, 2013 
All rights reserved.

Caio Waisman

Graduated in Economics from the Universidade de São Paulo in 2010 .

Bibliographic data

Waisman, Caio

The effects of exposure to hyperinflation on occupational choice / Caio Waisman; adviser: Eduardo Zilberman; co-adviser: João Manoel Pinho de Mello. - Rio de Janeiro : PUC-Rio, Departmento de Economia, 2013.

v., 39 f: il. ; $29,7 \mathrm{~cm}$

1. Dissertação de mestrado - Pontifícia Universidade Católica do Rio de Janeiro, Departmento de Economia.

Inclui referências bibliográficas.

1. Economia - Dissertação. 2. Escolha Ocupacional. 3. Hiperinflação. 4. Empreendorismo. 5. Imigrantes. I. Zilberman, Eduardo. II. Mello, João Manoel Pinho de. III. Pontifícia Universidade Católica do Rio de Janeiro. Departmento de Economia. IV. Título. 


\section{Acknowledgments}

Primeiramente, gostaria de agradecer aos meus orientadores, Dudu e João. Ao Dudu pela solicitude, disposição e entusiasmo, bem como por todas as conversas e trocas de ideias ao longo do processo de elaboração deste trabalho. Em especial, por sempre aturar e saber lidar com meus ceticismo e pessimismo, e por sempre ter se colocado como um colega pesquisador acima de qualquer outra coisa. Ao João por toda a amizade, orientação e apoio dados desde meu primeiro dia de visita à PUC, passando por um primeiro ano de mestrado deveras emocionante, pela minha primeira experiência como monitor e chegando até a conclusão desta dissertação. Os dois me ensinaram muito ao longo dos meses em que tive a oportunidade de trabalhar com eles, e espero ter correspondido ao menos em parte às suas expectativas. Também espero que possamos trabalhar juntos mais vezes no futuro.

Aos professores Gustavo Gonzaga e Miguel Foguel pela leitura atenta e cuidadosa deste trabalho. Acima de tudo, pelos comentários e sugestões que aumentaram sensivelmente a qualidade desta dissertação.

A todos os professores do departamento de economia da PUC com quem tive a oportunidade e privilégio de ter contato, especialmente aqueles de quem fui aluno e com quem aprendi tanto ao longo destes dois anos. Gostaria de agradecer especialmente aos professores Vinícius Carrasco e Marcelo Medeiros, que me convidaram para ser monitor, o que, por sua vez, me proporcionou um aprendizado ainda mais rico.

A todos os meus colegas de mestrado. Desde os veteranos que me incentivaram, deram conselhos e apoiaram nos momentos mais difíceis até os que foram expostos às minhas primeiras experiências como docente. Graças a eles minha experiência de mestrado não só foi mais alegre como também mais enriquecedora. Por isso, sempre lhes serei extremamente grato.

Ao CNPq e à FAPERJ pelo apoio financeiro.

Aos meus demais amigos e familiares pelo apoio e torcida. Em especial, ao meu tio Carlos por sempre tentar me indicar o que ele acredita ser o melhor para mim. Lamento nem sempre compreendê-lo. Também ao meu primo Rafael, por simbolizar ao mesmo tempo tudo o que família e amizade deveriam ser.

Por fim, ao meu pai, Jaime, para quem dedico este trabalho. Simplesmente não consigo colocar em palavras o quanto me sinto agradecido e em dívida por tudo que ele me proporcionou. Tenho certeza de que nada do que conquistei até hoje teria sido possível sem ele. Espero algum dia conseguir fazer jus a tudo que recebi. 


\section{Resumo}

Waisman, Caio; Zilberman, Eduardo; Mello, João Manoel Pinho de. Efeitos da experiência de hiperinflação em escolha ocupacional. Rio de Janeiro, 2013. 39p. Dissertação de Mestrado - Deparatmento de Economia, Pontifícia Universidade Católica do Rio de Janeiro.

Esta dissertação faz uso de dados sobre imigrantes que vivem no Estados Unidos para estudar os efeitos da experiência de hiperinflação em escolha ocupacional. Para isso, o número de anos que um indivíduo viveu sob hiperinflação antes de chegar ao EUA é calculado. Seu efeito marginal na probabilidade de ser autônomo ao invés de assalariado é de 0,87 ponto percentual. Este efeito depende da idade que o indivíduo tinha quando viveu a hiperinflação. Em particular, ele é mais forte para aqueles que viveram a hiperinflação quando jovens, mas desaparece para os que o fizeram com mais de 40 anos de idade. Estes resultados sugerem que o ambiente macroeconômico no qual um indivíduo cresce influencia permanentemente seu comportamento.

\section{Palavras-chave}

Escolha Ocupacional; Hiperinflação; Empreendorismo; Imigrantes. 


\begin{abstract}
Waisman, Caio; Zilberman, Eduardo; Mello, João Manoel Pinho de. The effects of exposure to hyperinflation on occupational choice. Rio de Janeiro, 2013. 39p. Master Thesis - Departmento de Economia, Pontifícia Universidade Católica do Rio de Janeiro.
\end{abstract}

This dissertation uses data on immigrants who live in the United States to study the effects of exposure to hyperinflation on occupational choice. To do so, the number of years an individual had lived under hyperinflation before arriving in the US is calculated. Its marginal effect on the probability of being self-employed instead of wage-earner is 0.87 percentage point. This effect depends on the age individuals had when exposed to hyperinflation. In particular, it is stronger for individuals who experienced hyperinflation at an early age, but it vanishes for those over the age of 40 . These results suggest that the macroeconomic environment an individual grows up in permanently affects his economic behavior.

\title{
Keywords
}

Occupational Choice; Hyperinflation; Self-Employment; Immigrants. 


\section{Contents}

$\begin{array}{llr}\text { I Introduction } & \mathbf{9}\end{array}$

II Data and Descriptive Statistics $\quad 13$

$\begin{array}{lrr}\text { III Empirical Strategy } & 18\end{array}$

IV Results $\quad 21$

V Extensions $\quad 24$

V.1 Age at the last hyperinflation experience 24

Less than 13 years of age 25

Between 18 and 25 years of age $\quad 25$

More than 40 years of age $\quad 26$

$\begin{array}{lll}\text { V.2 } & \text { Self-employed parents } & 27\end{array}$

V.3 Deep recessions 29

$\begin{array}{lll}\text { V.4 Wars } & 30\end{array}$

V.5 Propensity Score Results 31

$\begin{array}{ll}\text { VI Conclusion } & 37\end{array}$

$\begin{array}{ll}\text { Bibliography } & 38\end{array}$ 


\section{List of Tables}

II.1 Hyperinflation Episodes and Distribution of Immigrants Who Experienced Hyperinflation

II.2 Self-Employment Across Groups 16

$\begin{array}{lll}\text { II.3 Experience of Hyperinflation } & 17\end{array}$

IV.1 Hyperinflation and Self-Employment 22

V.1 Hyperinflation and Self-Employment (last experience of hyperinflation under 13 years of age)

V.2 Hyperinflation and Self-Employment (last experience of hyperinflation between 18 and 25 years of age)

V.3 Hyperinflation and Self-Employment (last experience of hyperinflation over 40 years of age)

V.4 Hyperinflation, Self-Employment and Self-Employed Parents 32

V.5 Hyperinflation, Self-Employment and Recessions (GDP growth smaller than 5 th percentile)

V.6 Hyperinflation, Self-Employment and Recessions (negative 3year moving average of GDP growth) 34

V.7 Hyperinflation, Self-Employment and Wars 35

V.8 Average Treatment Effect of Hyperinflation on Self-Employment 36 


\section{Introduction}

In this dissertation, I study the effects of exposure to hyperinflation on self-employment decisions. By using data on immigrants from the US Census and on inflation across countries from the dataset compiled by Reinhardt \& Rogoff (2009), I am able to calculate the number of years an individual had lived under hyperinflation before arriving in the US. I find evidence, consistent across several specifications, that experience of hyperinflation increases the probability of being self-employed rather than wage-earner. This effect depends on the age the individual had when exposed to hyperinflation. In particular, it is stronger at childhood and young adulthood. This finding suggests that the macroeconomic environment one grows up in permanently affects one's economic behavior. ${ }^{1}$

There are some reasons why hyperinflation can affect occupational choice. First, occupational choice is closely related to cash flow. A wage-earner, for instance, has a more rigid cash flow as he gets paid at a fixed schedule agreed in advance. In contrast, a self-employed individual can assure he gets paid once he sells his product. Moreover, he can easily adjust its price as inflation accelerates. This flexibility is desirable in times of hyperinflation once it allows the self-employed to protect himself against currency devaluations.

Notice that if wage indexation becomes mandatory, as it occurred in many episodes of hyperinflation, wage-earners could be more protected against currency devaluations than self-employed individuals. However, wage indexation itself exacerbates episodes of hyperinflation, not necessarily protecting wage-earners.

Second, as many governments attempted to fight high inflation by controlling wages and prices, the appearance of black markets was common

\footnotetext{
${ }^{1}$ These results fit into a growing literature, which ties experiences of macroeconomic events to economic behavior using data at the individual level. Recent examples are Giuliano \& Spilimbergo (2009) and Malmendier \& Nagel (2011). To my knowledge, only a few papers attempt to explain economic behavior using inflation experiences at the individual level. Lombardelli \& Saleheen (2003) as well as Malmendier \& Nagel (2012) investigate how subjective inflation expectations are shaped by experience of inflation. Ehrmann \& Tzamourani (2012) test whether experience of high inflation impacts the importance an individual attaches to price stability.
} 
during episodes of hyperinflation. This can be seen as evidence that the return to undertake risky projects in the informal sector increases in times of hyperinflation. Hence, individuals have more incentives to become an informal self-employed. ${ }^{2}$

Third, by living in a hyperinflation episode, individuals may develop skills and habits that can be profitably employed in an own business. For example, individuals may develop some financial literacy in order to save, plan in advance what to do with wages in order to protect themselves against large devaluations, and develop a habit of search and bargain for low prices as the price distribution becomes more disperse.

Finally, hyperinflation episodes are plagued with uncertainty. In particular, inflation becomes more volatile, which impairs risk assessment by investors. Hence, individuals may prefer to become wage-earners as self-employment requires more risk-taking. Moreover, from a behavioral perspective, uncertainty may affect positively risk aversion, which reinforces the aforementioned effect. Malmendier \& Nagel (2011), for instance, document that subjective experiences of macroeconomic shocks affect financial risk-taking.

The theoretical reasoning above suggests that, in principle, it is not clear how exposure to hyperinflation should impact the probability of being selfemployed. Hence, in order to sort out this effect, I devise an empirical strategy based on the"epidemiological approach" surveyed by Fernández (2011). ${ }^{3}$ In a sample restricted to immigrants in the US, I estimate, using a Probit model, the effect of years exposed to hyperinflation on the probability of being selfemployed instead of wage-earner. Notice that data on immigrants in the US are collected after they had experienced hyperinflation episodes. Hence, in order to rationalize my results, not only exposure to hyperinflation should affect current occupational choice, but also occupational choice itself should persist over time. Indeed, Akee et al. (2007) find that being self-employed in the country of birth affects positively the probability of being self-employed in the US. ${ }^{4}$

\footnotetext{
${ }^{2}$ Yuengert (1995) argues that "experience in the informal sector is a form of sector-specific human capital, inclining immigrants more towards self-employment in the United States" (page 196).

${ }^{3}$ By comparing outcomes for immigrants and natives, the "epidemological approach" attempts to separate the contribution of the environment from genes in disease. This approach has been adapted and extended by Carroll et al. (1994), Guiso et al. (2004), Fernández \& Fogli (2009), among others, to identify the role of culture in economic outcomes.

${ }^{4}$ One possible explanation is that becoming self-employed may require investment in specific human capital, which can be carried over to other countries. Another possible reason for this persistence is that hyperinflation is a traumatic macroeconomic event that can shape permanently preferences and beliefs; and, thus, behavior. Ehrmann \& Tzamourani (2012), for instance, find that memories of hyperinflation are permanent, while those of less severe
} 
Notice that immigrants are subject to the same environment in the US, a country that has never experienced hyperinflation. Hence, once I control for several covariates, I am able to separate the effect of exposure to hyperinflation from other potential determinants of self-employment, such as attributes of the country of birth, attributes of the area one lives in, and personal characteristics. ${ }^{5}$

I consider two different definitions of hyperinflation: the same used by Reinhardt \& Rogoff (2009) of a price level increase of at least 500 percent per year, and a less restrictive one of at least 100 percent per year. In order to mitigate the selection bias in immigration due to exposure to hyperinflation, I also run specifications that restrict the sample to individuals who immigrated at least five or ten years after the last year they had experienced hyperinflation.

According to my preferred specification, which considers individuals who immigrated at least five years after their last hyperinflation experience, the marginal effect of years lived under a 100 percent (500 percent) hyperinflation on the probability of being self-employed instead of wage-earner is 0.55 percentage point ( 0.87 percentage point). Given that self-employed individuals correspond to 8.9 percent of the sample used, these results are not negligible. Moreover, these effects depend on the age the individual had when exposed to hyperinflation. In particular, they are stronger for individuals who experienced hyperinflation at earlier ages (less than 13 years of age) and young adulthood (between 18 and 25 years of age), but insignificant for those over the age of 40 .

Lentz \& Laband (1990) and Dunn \& Holtz-Eakin (2000), among others, emphasize that the descendant of a self-employed is more likely to become self-employed himself. However, parents' occupational choice are omitted from my specifications as information on these variables is available only for those individuals who live with their parents. In this restricted sample, the estimated effects of exposure to hyperinflation reduce a bit once I control for parents' occupational choice, but remain significant. This result suggests that these omitted variables are not biasing much my findings.

Finally, one important concern is that hyperinflation episodes are associated with deep recessions. Hence, my results might be capturing the effect

inflation experiences vanish with time. In a similar vein, Giuliano \& Spilimbergo (2009) document that individuals who had experienced a recession - also a traumatic macroeconomic event - during their early adulthood have different beliefs from those who did not.

${ }^{5}$ There is a literature that deals with self-employment among immigrants in the US. One of the first articles is Borjas (1986), who documents that immigrants are more likely to be self-employed than native-born individuals. Moreover, the probability of being self-employed is heterogeneous across groups of immigrants. Following this study, many authors have tried to explain these results. Notable contributions include Yuengert (1995), Fairlie \& Meyer (1996), Fairlie \& Meyer (2000), Hout \& Rosen (2000), and Oyelere \& Belton (2012). 
of experience of recessions rather than hyperinflation. However, once I control for the number of years an individual had experienced recessions in his home country, defined in a similar fashion to Giuliano \& Spilimbergo (2009), estimated marginal effects are almost the same. The link between hyperinflation episodes and wars gives rise to a similar concern, which is addressed by controlling for a dummy which indicates whether the individual experienced a war. Once again, estimated marginal effects barely change. 


\section{II}

\section{Data and Descriptive Statistics}

I use two data sources in this paper. Information on immigrants comes from the US Census and is provided by the Integrated Public Use Microdata Series (IPUMS), ${ }^{1}$ whereas information on inflation comes from the dataset compiled by Reinhardt \& Rogoff (2009). ${ }^{2}$

The variables of interest are self-employment and the number of years an individual had lived under hyperinflation. The former is obtained from IPUMS using the variable labeled CLASSWKR, which reports whether the individual is self-employed or work for wages. I exclude immigrants who are not classified into any of these classes. To calculate the latter variable, I use Census information on birth date, year of immigration to the US, and country of birth at the individual level. Hence, by using information on all hyperinflation episodes someone has faced during his lifespan, I am able to proxy the number of years this individual was exposed to hyperinflation. ${ }^{3}$

I consider the five percent sample from the 2000 Census. I did not use earlier samples as information on year of immigration is not precise. In the 1980 and 1990 Censuses, for example, all immigrants who arrived in the US between 1950 and 1959 are grouped into a single category. ${ }^{4}$ In contrast, the information from the 2000 Census is precise except for immigrants who arrived in the US before 1919. In particular, immigrants who arrived in the US before 1910 are grouped into a single category and, thus, excluded from the analysis. For individuals whose exact year of immigration was not known, but the interval in which they immigrated was, I rounded it at the lower bound of this interval. Hence, individuals who arrived in the US between 1911 and 1914 as well as between 1915 and 1919 were considered to have immigrated in 1911 and 1915, respectively. ${ }^{5}$ I choose to round at the lower bound because, by underestimating

${ }^{1}$ Available at http://usa.ipums.org/usa/.

${ }^{2}$ Available at http://www.reinhartandrogoff.com/.

${ }^{3}$ As someone may had lived in more than one country before immigrating to the US, this variable is measured with a slight noise.

${ }^{4}$ In the 1990 Census, for instance, categories are 1949 or earlier, 1950-1959, 1960-1964, 1965-1969, 1970-1974, 1975-1979, 1980-1981, 1982-1984, 1985-1986, and 1987-1990, which would introduce much more noise in my measure of exposure to hyperinflation.

${ }^{5}$ Due to this adjustment, 578 observations present a year of immigration prior to the year 
an individual's experience of hyperinflation, I also underestimate its effect on self-employment. ${ }^{6}$

The dataset on inflation contains information on 70 countries. $^{7}$ I discard individuals from countries for which data on inflation are not available. Moreover, a complete record of inflation was not available for all countries. Hence, I only consider individuals for whom information on inflation experienced is available during their lifespan. ${ }^{8}$

I use two different definitions of hyperinflation: the same used by Reinhardt \& Rogoff (2009) of a price level increase of at least 500 percent per year, and a less restrictive one of at least 100 percent per year. ${ }^{9}$ The use of these two criteria allows me to find out whether there is a difference in behavior due to the intensity of the hyperinflation experienced.

I end up with information on 757,702 immigrants. ${ }^{10} \mathrm{~A}$ share of 32.2 percent of these immigrants had experienced at least one year of 100 percent hyperinflation, whereas 3.8 percent had experienced at least one year of 500 percent hyperinflation. Since no one in the final sample was born before 1900, only 20th century hyperinflation episodes are considered. There is variation over time, as every decagon since the 1910s presents at least one episode of hyperinflation, and across the world: South America (e.g. Argentina), Central America (e.g. Nicaragua), North America (only Mexico), Africa (e.g. Ghana), Western Europe (e.g. Germany), Eastern Europe (e.g. Poland), Middle East (only Turkey), Southeast Asia (e.g. Indonesia) and Far East (e.g. China). See Table II.1 for a list of all hyperinflation episodes and the distribution of immigrants who experienced hyperinflation across countries.

In Table II.2, Panel A, I report means and standards deviations for a of birth. They are also excluded from the analysis.

${ }^{6}$ Only 76 out of 757,702 cases in the final sample need this adjustment, so the distortion in estimates should be minimum.

${ }^{7}$ These countries are Algeria, Angola, Argentina, Australia, Austria, Belgium, Bolivia, Brazil, Canada, Central African Republic, Chile, China, Colombia, Costa Rica, Denmark, Dominican Republic, Ecuador, Egypt, El Salvador, Finland, France, Germany, Ghana, Greece, Guatemala, Honduras, Hungary, Iceland, India, Indonesia, Ireland, Italy, Ivory Coast, Japan, Kenya, Korea, Malaysia, Mauritius, Mexico, Morocco, Myanmar, Netherlands, New Zealand, Nicaragua, Nigeria, Norway, Panama, Paraguay, Peru, Philippines, Poland, Portugal, Romania, Russia, Singapore, South Africa, Spain, Sri Lanka, Sweden, Switzerland, Taiwan, Thailand, Tunisia, Turkey, United Kingdom, Uruguay, USA, Venezuela, Zambia, Zimbabwe.

${ }^{8}$ For example, since information on Chinese inflation are not available from 1949 to 1962, all individuals who were born in China before 1962 and immigrated after 1949 are excluded from the sample. A similar disclaimer applies to Russia, for example.

${ }^{9}$ Since I do not have monthly inflation data, I am not able to use the traditional hyperinflation definition due to Cagan (1956) in which monthly inflation exceeded 50 percent at least three months in a row.

${ }^{10}$ Throughout the tables, I weight descriptive statistics and estimates using person weights. Thus, 238 individuals who have zero weights are also excluded from the final sample. 
Table II.1: Hyperinflation Episodes and Distribution of Immigrants Who Experienced Hyperinflation

\begin{tabular}{|c|c|c|c|c|c|c|c|c|}
\hline Countries & $\begin{array}{l}\text { Years under } \\
\text { hyperinflation } \\
\text { of } 100 \%\end{array}$ & $\begin{array}{l}\text { Whole } \\
\text { sample }\end{array}$ & $\begin{array}{l}\text { Immig. } \\
>5 \text { years }\end{array}$ & $\begin{array}{l}\text { Immig. } \\
>10 \text { years }\end{array}$ & $\begin{array}{l}\text { Years under } \\
\text { hyperinflation } \\
\text { of } 500 \%\end{array}$ & $\begin{array}{l}\text { Whole } \\
\text { sample }\end{array}$ & $\begin{array}{l}\text { Immig. } \\
>5 \text { years }\end{array}$ & $\begin{array}{l}\text { Immig. } \\
>10 \text { years }\end{array}$ \\
\hline Angola & $1924,1991-2000$ & $0 \%$ & $0 \%$ & $0 \%$ & $1993-6$ & $0 \%$ & $0 \%$ & $0 \%$ \\
\hline Argentina & $1959,1975-85,1987-91$ & $1.61 \%$ & $1.27 \%$ & $0.94 \%$ & $1984-5,1989-90$ & $0.77 \%$ & $6.98 \%$ & $0 \%$ \\
\hline Austria & $1916,1919-20,1922$ & $0.02 \%$ & $0.05 \%$ & $0.13 \%$ & 1922 & $0.17 \%$ & $0.45 \%$ & $0.91 \%$ \\
\hline Bolivia & $1953-4,1956-7,1960,1982-6$ & $0.67 \%$ & $0.85 \%$ & $1.43 \%$ & $1984-5$ & $3.78 \%$ & $5.51 \%$ & $6.10 \%$ \\
\hline Brazil & 1981-94 & $2.49 \%$ & $0.32 \%$ & $0 \%$ & $1988-90,1992-4$ & $417.04 \%$ & $3.01 \%$ & $0 \%$ \\
\hline Chile & $1972-6$ & $0.83 \%$ & $1.29 \%$ & $2.94 \%$ & 1973 & $6.22 \%$ & $13.63 \%$ & $22.87 \%$ \\
\hline China & $1913,1939,1941-8$ & $0.09 \%$ & $0.003 \%$ & $0.01 \%$ & $1946-8$ & $0.48 \%$ & $0 \%$ & $0 \%$ \\
\hline Finland & 1918 & $0.001 \%$ & $0.001 \%$ & $0.004 \%$ & & & & \\
\hline Germany & $1920,1922-3$ & $0.08 \%$ & $0.12 \%$ & $0.23 \%$ & $1922-3$ & $0.64 \%$ & $1.10 \%$ & $1.62 \%$ \\
\hline Ghana & $1977,1981,1983$ & $0.85 \%$ & $1.42 \%$ & $2.80 \%$ & & & & \\
\hline Greece & $1945-6$ & $0.13 \%$ & $0.29 \%$ & $0.83 \%$ & 1946 & $1.07 \%$ & $2.75 \%$ & $5.70 \%$ \\
\hline Hungary & $1945-6$ & $0.42 \%$ & $0.87 \%$ & $1.98 \%$ & $1945-6$ & $3.52 \%$ & $8.26 \%$ & $13.61 \%$ \\
\hline Indonesia & $1962-8$ & $0.51 \%$ & $0.94 \%$ & $2.49 \%$ & 1966 & $3.46 \%$ & $8.25 \%$ & $16.13 \%$ \\
\hline Italy & 1944 & $1.80 \%$ & $3.88 \%$ & $10.06 \%$ & & & & \\
\hline Japan & 1945,1947 & $0.87 \%$ & $1.96 \%$ & $5.20 \%$ & 1945 & $6.27 \%$ & $16.66 \%$ & $33.05 \%$ \\
\hline Korea & 1952 & $0.18 \%$ & $0.42 \%$ & $1.27 \%$ & & & & \\
\hline Mexico & $1983,1987-8$ & $79.85 \%$ & $81.68 \%$ & $67.93 \%$ & & & & \\
\hline Nicaragua & 1984-91 & $1.91 \%$ & $0.42 \%$ & $0 \%$ & $1985-90$ & $14.73 \%$ & $5.03 \%$ & $0 \%$ \\
\hline Paraguay & 1952 & $0.04 \%$ & $0.08 \%$ & $0.23 \%$ & & & & \\
\hline Peru & $1983-85,1988-91$ & $2.76 \%$ & $1.13 \%$ & $0 \%$ & $1988-90$ & $17.26 \%$ & $13.84 \%$ & $0 \%$ \\
\hline Philippines & 1943 & $0.0003 \%$ & $0 \%$ & $0 \%$ & & & & \\
\hline Poland & $1922,1924,1982,1989-90$ & $3.58 \%$ & $1.96 \%$ & $0.02 \%$ & 1922,1990 & $18.60 \%$ & $14.54 \%$ & $0.02 \%$ \\
\hline Romania & $1990-4,1997$ & $0.24 \%$ & $0 \%$ & $0 \%$ & & & & \\
\hline Russia & $1993-5$ & $0 \%$ & $0 \%$ & $0 \%$ & 1993 & $0 \%$ & $0 \%$ & $0 \%$ \\
\hline Turkey & 1916-17, 1980, 1994 & $0.77 \%$ & $0.64 \%$ & $0.73 \%$ & & & & \\
\hline Uruguay & $1968,1990,1991$ & $0.31 \%$ & $0.42 \%$ & $0.78 \%$ & & & & \\
\hline Zambia & $1989-90,1992-3$ & $0 \%$ & $0 \%$ & $0 \%$ & & & & \\
\hline
\end{tabular}

Sources: Author's calculations from the 5 percent 2000 Sample of the US Census, and the dataset compiled by Reinhardt and Rogoff (2009).

The columns under "immig. $>5$ (10) years" consider immigrants who immigrated 5 (10) years after their last experience of hyperinflation.

variable indicating if the individual is self-employed rather than wage-earner for the whole sample, those who experienced hyperinflation of 100 percent, and those who experienced hyperinflation of 500 percent. Given that this is a dummy variable, the mean is the share of self-employed individuals in the sample. The share of self-employed workers amongst those who experienced hyperinflation of 100 percent is 7.4 percent. This figure is smaller than the share of the whole sample, which is 8.9 percent. In contrast, the share of selfemployed individuals amongst those who experienced hyperinflation of 500 percent is 12.6 percent, which is considerably larger.

In Table II.3, Panel A, I report means and standard deviations for the years individuals had lived under hyperinflation according to both criteria. Despite the difference in the number of observations, the means are not that 
Table II.2: Self-Employment Across Groups

\begin{tabular}{|c|c|c|c|c|}
\hline \multicolumn{5}{|c|}{ Panel A: Whole sample } \\
\hline & Mean & S.D. & Observations & $\%$ of sample \\
\hline Experienced hyperinflation of $100 \%$ & 0.074 & 0.261 & 243,817 & $32.18 \%$ \\
\hline Experienced hyperinflation of $500 \%$ & 0.126 & 0.332 & 28,375 & $3.74 \%$ \\
\hline Whole sample & 0.089 & 0.285 & 757,702 & $100 \%$ \\
\hline \multicolumn{5}{|c|}{ Panel B: 5-year window } \\
\hline & Mean & S.D. & Observations & $\%$ of sample \\
\hline Experienced hyperinflation of $100 \%$ & 0.066 & 0.248 & 101,615 & $19.11 \%$ \\
\hline Experienced hyperinflation of $500 \%$ & 0.136 & 0.343 & 10,488 & $1.97 \%$ \\
\hline Whole sample & 0.094 & 0.292 & 531,607 & $100 \%$ \\
\hline \multicolumn{5}{|c|}{ Panel C: 10-year window } \\
\hline & Mean & S.D. & Observations & $\%$ of sample \\
\hline Experienced hyperinflation of $100 \%$ & 0.085 & 0.279 & 33,169 & $7.89 \%$ \\
\hline Experienced hyperinflation of $500 \%$ & 0.183 & 0.387 & 4,814 & $1.15 \%$ \\
\hline Whole sample & 0.102 & 0.303 & 420,362 & $100.00 \%$ \\
\hline
\end{tabular}

Sources: Author's calculations from the 5 percent 2000 Sample of the US Census, and the dataset compiled by Reinhardt and Rogoff (2009).

different between the two groups. Indeed, average years are 3.0 and 2.7 for the 100 and 500 percent criteria, respectively. However, the maximum values are contrasting. Under the 100 percent criterion, the maximum value is 17 (Argentineans) while under 500 percent it is six (Brazilians and Nicaraguans).

Finally, as I explain below, in order to mitigate a selection effect in immigration due to hyperinflation, I also run specifications restricted to individuals who immigrated more than five and ten years after their last hyperinflation experience. Table II.1 and Panels B and C of Tables II.2 and II.3 also report descriptive statistics for these selected samples. ${ }^{11}$

\footnotetext{
${ }^{11}$ Notice that the number of individuals who have not experienced hyperinflation changes across samples. By construction, once we restrict the sample to individuals who immigrated more than five (ten) years after their last hyperinflation experience, those necessarily were at least six (eleven) years of age when they immigrated. Hence, in order to not introduce a bias in myresults, I also exclude individuals who were at most five (ten) years of age when they immigrated from this restricted sample.
} 
Table II.3: Experience of Hyperinflation

\begin{tabular}{|c|c|c|}
\hline \multicolumn{3}{|c|}{ Panel A: Whole sample } \\
\hline & $100 \%$ & $500 \%$ \\
\hline Mean & 3.035 & 2.697 \\
\hline S.D. & 2.162 & 1.847 \\
\hline Max value & 17 & 6 \\
\hline No. of observations & 243,817 & 28,375 \\
\hline \multicolumn{3}{|c|}{ Panel B: 5-year window } \\
\hline & $100 \%$ & $500 \%$ \\
\hline Mean & 3.062 & 2.031 \\
\hline S.D. & 1.470 & 1.507 \\
\hline Max value & 17 & 6 \\
\hline No. of observations & 101,615 & 10,488 \\
\hline \multicolumn{3}{|c|}{ Panel $C: 10$-year window } \\
\hline & $100 \%$ & $500 \%$ \\
\hline Mean & 2.742 & 1.203 \\
\hline S.D. & 1.054 & 0.403 \\
\hline Max value & 10 & 2 \\
\hline No. of observations & 33,169 & 4,814 \\
\hline
\end{tabular}




\section{III}

\section{Empirical Strategy}

In order to investigate the impact of exposure to hyperinflation on the probability of self-employment, I estimate a Probit model given by the equation below.

$$
\operatorname{Prob}\left(Y_{i}=1 \mid \text { hyperinflation }_{i}, X_{i}\right)=\Phi\left(\beta \times \text { hyperinflation }_{i}+X_{i}^{\prime} \gamma\right)
$$

The dependent variable, $Y_{i}$, is a dummy variable that indicates whether the immigrant $i$ is self-employed $\left(Y_{i}=1\right)$ or wage-earner $\left(Y_{i}=0\right)$. $\Phi$ is the standard normal cumulative distribution function. hyperinflation $n_{i}$ is the number of years of hyperinflation the individual $i$ had experienced. Finally, the vector $X_{i}$ includes all remaining covariates, which are: financial income and dummies for: the number of years passed since the individual immigrated, metropolitan area, relationship towards the head of the household, age, race, gender, marital status, country of birth, level of educational attainment and house ownership. ${ }^{1}$

The identification strategy is based on the "epidemiological approach" surveyed by Fernández (2011). Notice that immigrants are subject to the same environment in the US, a country that has never experienced hyperinflation. Moreover, the degree of assimilation to the US environment is taken into consideration by the variable of years passed since immigration. Hence, once I control for several covariates, I am able to separate the effect of exposure to hyperinflation from other potential determinants of self-employment. In other words, the comparison of immigrants who have experienced hyperinflation before immigrating to immigrants who have not recovers the causal effect of interest.

By controlling for the metropolitan area an individual lives in, I am accounting for the effect of labor market conditions and institutions might have on self-employment. Similarly, by using dummies for home countries,

${ }^{1}$ The number of years passed since the individual immigrated is calculated using the year of immigration. The remaining variables are readily available at IPUMS. In particular, financial income is the variable labeled INCINVST, which sums interest, dividend, and rental income. 
I am accounting for all cultural and institutional effects related to the country of birth. ${ }^{2}$ Finally, I am controlling for several personal characteristics that are documented to be correlated with self-employment, such as education (e.g. Lazear (2005)), race (e.g. Fairlie \& Meyer (1996) and Fairlie \& Meyer (2000)), proxies for wealth (e.g. Evans \& Jovanovic (1989) and Hurst \& Lusardi (2004)), ${ }^{3}$ gender (e.g. Georgellis \& Wall (2005)), and so on. ${ }^{4}$

One important omitted variable, due to data availability, is parents' occupational choice. As Dunn \& Holtz-Eakin (2000) emphasize, the descendant of a self-employed is more likely to become self-employed himself. I tackle this concern in Section V.2.

The remaining identification issue regards selection. It is likely that hyperinflation itself affects the decision to immigrate. Moreover, it is also likely that individuals who immigrated due to hyperinflation are different from those who would have immigrated anyway. Hence, by comparing these two kinds of immigrants, a selection bias arises. In order to account for this bias, I consider two alternative specifications, in which the sample is restricted to individuals who immigrated more than five and ten years after their last hyperinflation experience. ${ }^{5}$ I expect that these individuals immigrated for other reason than hyperinflation. ${ }^{6}$

The age someone had when exposed to hyperinflation is crucial to determine whether it affects his occupational choice. For example, at later ages, an adult probably has an established occupation. Hence, it is unlikely that hyperinflation would affect his occupational choice. I address this heterogeneity by selecting three subsamples according to the age individuals had when they experienced hyperinflation for the last time. Results are presented in Section V.1.

${ }^{2}$ Notice that these dummies control for the heterogeneity in self-employment across different groups of immigrants as documented by Borjas (1986).

${ }^{3}$ Following Oyelere \& Belton (2012), I include financial income and home ownership as proxy for wealth. By mitigating borrowing constraints, wealth increases the probability of being self-employed.

${ }^{4}$ Notice I am not controlling for the presence of local colonies of immigrants. Yuengert (1995), for instance, did not find evidence supporting effects of local colonies of immigrants on self-employment.

${ }^{5}$ Recall that, once I restrict the sample to individuals who immigrated more than five (ten) years after their last hyperinflation experience, those necessarily were at least six (eleven) years of age when they immigrated. Hence, in order to not introduce a bias in the estimated effect, I exclude from this restricted sample all individuals who were at most five (ten) years of age when they immigrated.

${ }^{6}$ One might argue that if hyperinflation is severe enough, an individual may suffer substantial losses. Hence, it would take time for him to accumulate enough savings, so he can afford to leave his country. However, it is unlikely that this accumulation process endures for ten years. 
Moreover, potential concerns are that hyperinflation episodes are associated with deep recessions and wars. Hence, my regressions might be capturing the effect of such experiences rather than hyperinflation. I address these issues in Sections V.3 and V.4.

Finally, I also estimate the effect of interest under a treatment effect framework using propensity score matching. The treatment in this case is assigned by a dummy indicating whether an individual has experienced hyperinflation or not. Results are presented in section V.5. 


\section{IV}

\section{Results}

This chapter shows the benchmark results. Throughout the paper, I report the marginal effects, evaluated at the means of the covariates, for several specifications of the estimated Probit model described in the previous chapter. Since exposure to hyperinflation varies with country of birth and year of immigration, standard errors are always corrected for clustering at this pair of variables.

In order to compare the magnitude of the estimated marginal effects for both criteria of hyperinflation, I exclude individuals that experienced hyperinflation between 100 and 500 percent from the sample whenever we consider the 500 percent hyperinflation criterion. In other words, I keep the same "control group" in all regressions.

Throughout the tables, I report the share of the sample that has experienced hyperinflation to show that I have enough observations to estimate the effect of interest.

Table IV.1 reports the marginal effect of hyperinflation on selfemployment. First, consider the 100 percent hyperinflation criterion. In the sample without restrictions (first column), this effect is 0.36 percentage point. If I restrict the sample for individuals who have immigrated at least five and ten years after their last hyperinflation, which mitigates the selection bias, the marginal effect increases to 0.55 and 0.77 percentage point (second and third columns), respectively. ${ }^{1}$

This same pattern is present once I consider the 500 percent hyperinflation criterion. The marginal effect increases from 0.68 to 0.87 and 1.3 percentage points once I restrict the sample to individuals who have immigrate at least five and ten years, respectively, after their last hyperinflation experience. This suggests that sample selection reduces the effect of hyperinflation on the probability of being self-employed instead of a wage-earner. Given that

\footnotetext{
${ }^{1}$ Notice that number of observations in Table IV.1 is different from Table II.2. Some observations are excluded from the regressions as there are some metropolitan areas where all the observed individuals are either self-employed or wage-earner. For example, Gadsen, which encompasses Etowah County, Alabama.
} 
Table IV.1: Hyperinflation and Self-Employment

\begin{tabular}{|c|c|c|c|}
\hline \multicolumn{4}{|c|}{ Dependent variable: dummy that equals 1 if self-employed and 0 if wage-earner } \\
\hline & \multicolumn{3}{|c|}{ Hyperinflation of $100 \%$ per year } \\
\hline & \multicolumn{3}{|c|}{ Years between last hyperinflation and immigration } \\
\hline & No restrictions & More than 5 & More than 10 \\
\hline hyperinflation & $\begin{array}{l}0.00359^{* * *} \\
(0.000397)\end{array}$ & $\begin{array}{c}0.00555^{* * *} \\
(0.000798)\end{array}$ & $\begin{array}{c}0.00777^{* * *} \\
(0.00160)\end{array}$ \\
\hline No. of observations & 757,286 & 531,227 & 420,055 \\
\hline \multirow[t]{4}{*}{$\%$ that experienced hyperinflation } & $32.2 \%$ & $19.1 \%$ & $7.9 \%$ \\
\hline & \multicolumn{3}{|c|}{ Hyperinflation of $500 \%$ per year } \\
\hline & \multicolumn{3}{|c|}{ Years between last hyperinflation and immigration } \\
\hline & No restrictions & More than 5 & More than 10 \\
\hline hyperinflation & $\begin{array}{l}0.00686^{* * *} \\
(0.000927)\end{array}$ & $\begin{array}{c}0.00876^{* * *} \\
(0.00162)\end{array}$ & $\begin{array}{c}0.0129^{* * *} \\
(0.00411)\end{array}$ \\
\hline $\begin{array}{l}\text { No. of observations } \\
\% \text { that experienced hyperinflation }\end{array}$ & $\begin{array}{c}541,897 \\
5.2 \%\end{array}$ & $\begin{array}{l}440,117 \\
2.4 \%\end{array}$ & $\begin{array}{l}391,688 \\
1.2 \%\end{array}$ \\
\hline
\end{tabular}

Notes: All specifications include a constant and the following covariates: financial income, and dummies for: years passed since immigration, metropolitan area, relationship to the household head, age, sex, race, marital status, country of birth, educational attainment and house ownership. Robust standard errors in parentheses account for clustering at the country of birth and year of immigration

*** Significant at the 1 percent level.

**Significant at the 5 percent level.

* Significant at the 10 percent level.

self-employed individuals correspond to 8.9 percent of the whole sample, these results are not negligible. ${ }^{2}$

Notice that the effect is always higher under the criterion of 500 percent rather than of 100 percent. This suggests that more intense experiences, in the sense of an exposure to higher levels of hyperinflation, have larger effects on the probability of being self-employed instead of a wage-earner.

As I mentioned in the introduction, I conjecture a few reasons why a positive effect could be the case. First, self-employed individuals have a more flexible cash flow which is valuable in times of hyperinflation. Second, selfemployment might be more attractive as business owners can adjust the price of their products as inflation accelerates. Third, hyperinflation episodes are associated with the emergence of black markets, which may provide incentives for individuals to become an informal self-employed. Finally, by living during a hyperinflation episode, individuals may develop skills and habits, such as

${ }^{2}$ The share of self-employed individuals is 9.4 (10.2) percent in the sample restricted by the five-year (ten-year) window between the last experience and immigration (see Table II.2). 
financial literacy, that can be profitably employed in an own business. 


\section{Extensions}

In this chapter, I present five extensions. The first extension presents results for three subsamples selected according to the age individuals had when they experienced hyperinflation for the last time. In particular, I consider individuals who were less than 13, between 18 and 25, and more than 40 years of age. I show that hyperinflation affects occupational choice asymmetrically across groups.

In the second extension, I address the sensitivity of my results to the inclusion of the occupational choice of someone's parents, an omitted variable that is documented to affect the probability of being self-employed. I argue that, if this omission was accounted for, results would not change much.

The third extension concerns the effect of recessions on self-employment. Once hyperinflation episodes are usually associated with deep recessions, my results could be capturing the effects of exposure to deep recessions instead. I claim this is not the case.

The fourth extension deals with effects of experiencing wars on selfemployment. Because many hyperinflation episodes were consequences of wars, the effect captured by the variable of experience of hyperinflation might be in fact associated to wars. Once again, I refute this possibility.

Finally, the fifth extension uses propensity score matching framework to estimate the effect of interest. I show that the results of this exercise are similar to the previous ones.

\section{V.1 Age at the last hyperinflation experience}

The age someone had when exposed to hyperinflation matters. For example, it is less likely that an adult with an established occupation would change it due to hyperinflation. In order to address this heterogeneity, I divide the sample into three groups according to the age individuals had when they experienced hyperinflation for the last time. These groups are composed by individuals who experienced hyperinflation at childhood (less than 13 years of 
age), early adulthood (between 18 and 25 years of age), and late adulthood (more than 40 years of age).

Notice that these sample selections impose restrictions on the age someone had at the year of immigration. For example, individuals who were between 18 and 25 years at their last hyperinflation experience immigrated at least at the age of 18. Hence, in order to not introduce a bias in the estimates, I exclude individuals who were at most 17 years of age when they immigrated to the US. If I further impose a five-year window between the last experience and immigration, I also exclude those who were at most 22 years of age.

Finally, I do not report results for the restricted sample that imposes a ten-year window between the years of last hyperinflation experience and immigration. Given that the sample is split by age groups, if I further impose this ten-year window, I end up with very few immigrants who experienced hyperinflation in some subsamples. For example, under the 500 percent hyperinflation criterion, there are only 27 immigrants at late adulthood who experienced hyperinflation. Hence, there is not enough variation to estimate the effect of interest.

\section{(a) Less than 13 years of age}

Table V.1 reports the results for individuals who experienced their last hyperinflation experience at childhood.

Notice that marginal effects are larger than those reported in Table IV.1. In particular, the marginal effect of exposure to hyperinflation is 1.1 (0.9) percentage point once considered the 100 (500) percent hyperinflation criterion and the five-year window restriction between the last experience and immigration. This finding suggests that the macroeconomic environment one grows up in permanently affects his economic behavior.

In principle, it is not intuitive that hyperinflation experiences at such early ages affect the occupation chosen years later. One possible explanation is that hyperinflation affects beliefs and behavior of parents, which are transmitted to the next generation. Unfortunately, the available data are not enough to test this hypothesis.

\section{(b) Between 18 and 25 years of age}

Table V.2 reports the results for individuals who experienced their last hyperinflation experience at early adulthood.

Notice that marginal effects are larger than those reported in Table IV.1. In particular, the marginal effect of experience to hyperinflation episodes is 0.67 
Table V.1: Hyperinflation and Self-Employment (last experience of hyperinflation under 13 years of age)

\begin{tabular}{lcc}
\hline \hline Dependent variable: dummy that equals 1 if self-employed and 0 if wage-earner \\
\cline { 2 - 3 } & \multicolumn{2}{c}{ Hyperinflation of $100 \%$ per year } \\
\cline { 2 - 3 } & \multicolumn{2}{c}{ Years between last hyperinflation and immigration } \\
\cline { 2 - 3 } & No restrictions & More than 5 \\
\hline hyperinflation & $0.00862^{* * *}$ & $0.0110^{* * *}$ \\
& $(0.000889)$ & $(0.00118)$ \\
No. of observations & 591,142 & 477,606 \\
$\%$ that experienced hyperinflation & $13.14 \%$ & $10.05 \%$ \\
\hline \hline
\end{tabular}

\begin{tabular}{lcc}
\hline & \multicolumn{2}{c}{ Hyperinflation of $500 \%$ per year } \\
\cline { 2 - 3 } & \multicolumn{2}{c}{ Years between last hyperinflation and immigration } \\
\cline { 2 - 3 } & No restrictions & More than 5 \\
\hline hyperinflation & $0.00622^{* * *}$ & $0.00901^{* * *}$ \\
& $(0.00202)$ & $(0.00327)$ \\
No. of observations & 520,976 & 434,235 \\
$\%$ that experienced hyperinflation & $1.43 \%$ & $1.11 \%$ \\
\hline \hline
\end{tabular}

Notes: All specifications include a constant and the following covariates: financial income, and dummies for:years passed since immigration, metropolitan area, relationship to the household head, age, sex, race, marital status, country of birth, educational attainment and houseownership. Robust standard errors in parentheses account for clustering at the country of birth and year of immigration.

*** Significant at the 1 percent level.

**Significant at the 5 percent level.

*Significant at the 10 percent level.

(1.32) percentage point(s) once considered the 100 (500) percent hyperinflation criterion and the five-year window restriction between the last experience and immigration.

As Giuliano \& Spilimbergo (2009) emphasize, between 18 and 25 years of age are the so-called formative years, during which beliefs and behavior are more susceptible to change. Moreover, most individuals choose their occupations for the first time during early adulthood. Hence, the macroeconomic environment one lives in during these years is especially relevant. Indeed, the estimated effect is particularly strong once considered the 500 percent hyperinflation criterion, which is a much more severe and traumatic event.

\section{(c) More than 40 years of age}

Table V.3 reports the results for individuals who experienced their last hyperinflation experience at late adulthood.

In this case, effects are not statistically significant in all cases. Intuitively, as changing occupations is costly, it is less likely that someone who has an 
Table V.2: Hyperinflation and Self-Employment (last experience of hyperinflation between 18 and 25 years of age)

\begin{tabular}{lcc}
\hline \hline Dependent variable: dummy that equals 1 if self-employed and 0 if wage-earner \\
\cline { 2 - 3 } & \multicolumn{3}{c}{ Hyperinflation of $100 \%$ per year } \\
\cline { 2 - 3 } & \multicolumn{3}{c}{ Years between last hyperinflation and immigration } \\
\cline { 2 - 3 } & No restrictions & More than 5 \\
\hline hyperinflation & $0.00552^{* * *}$ & $0.00668^{* * *}$ \\
& $(0.000670)$ & $(0.00127)$ \\
No. of observations & 361,364 & 199,570 \\
$\%$ that experienced hyperinflation & $16.68 \%$ & $8.74 \%$ \\
\hline \hline
\end{tabular}

\begin{tabular}{lcc}
\hline \hline & \multicolumn{2}{c}{ Hyperinflation of $500 \%$ per year } \\
\cline { 2 - 3 } & \multicolumn{3}{c}{ Years between last hyperinflation and immigration } \\
\cline { 2 - 3 } & No restrictions & More than 5 \\
\hline hyperinflation & $0.0125^{* * *}$ & $0.0132^{* * *}$ \\
& $(0.00175)$ & $(0.00271)$ \\
No. of observations & & \\
$\%$ that experienced hyperinflation & 308,105 & 184,044 \\
\hline \hline
\end{tabular}

Notes: All specifications include a constant and the following covariates financial income, and dummies for: years passed since immigration, metropolitan area, relationship to the household head, age, sex, race, marital status, country of birth, educational attainment and houseownership. Robust standard errors in parentheses account for clustering at the country of birth and year of immigration.

*** Significant at the 1 percent level.

**Significant at the 5 percent level.

*Significant at the 10 percent level.

established occupation would change it due to hyperinflation.

\section{V.2 Self-employed parents}

Data on parents' occupational choice, which is documented to affect positively the probability of being self-employed, are not directly available in the Census. Hence, this variable is omitted from my main regressions. In order to tackle this concern, I check, in a considerably smaller sample, how sensitive are the estimated marginal effects of hyperinflation experiences to the inclusion of this variable. In particular, as long as an individual lives with his parents in the same household, I can use information on relationship to the head of the household to trace back information on his parents' occupational choice.

Notice that this is a highly selected sample and, thus, individuals are considerably different from the average individual in the whole sample. Hence, the estimated marginal effects on this particular sample cannot be generalized. 
Table V.3: Hyperinflation and Self-Employment (last experience of hyperinflation over 40 years of age)

\begin{tabular}{lcc}
\hline \hline Dependent variable: dummy that equals 1 if self-employed and 0 if wage-earner \\
\cline { 2 - 3 } & \multicolumn{2}{c}{ Hyperinflation of $100 \%$ per year } \\
\cline { 2 - 3 } & \multicolumn{2}{c}{ Years between last hyperinflation and immigration } \\
\cline { 2 - 3 } & No restrictions & More than 5 \\
\hline hyperinflation & 0.00249 & 0.00389 \\
& $(0.00186)$ & $(0.00409)$ \\
No. of observations & 25,982 & 10,591 \\
$\%$ that experienced hyperinflation & $28.45 \%$ & $22.83 \%$ \\
\hline \hline
\end{tabular}

\begin{tabular}{lcc}
\hline & \multicolumn{2}{c}{ Hyperinflation of $500 \%$ per year } \\
\cline { 2 - 3 } & \multicolumn{2}{c}{ Years between last hyperinflation and immigration } \\
\cline { 2 - 3 } & No restrictions & More than 5 \\
\hline hyperinflation & -0.00550 & 0.00314 \\
& $(0.00613)$ & $(0.0148)$ \\
No. of observations & & \\
$\%$ that experienced hyperinflation & 20,001 & 8,422 \\
\hline \hline
\end{tabular}

Notes: All specifications include a constant and the following covariates: financial income, and dummies for: years passed since immigration, metropolitan area, relationship to the household head, age, sex, race, marital status, country of birth, educational attainment and houseownership. Robust standard errors in parentheses account for clustering at the country of birth and year of immigration.

*** Significant at the 1 percent level.

**Significant at the 5 percent level.

*Significant at the 10 percent level.

My aim, instead, is to verify how these estimates are affected by the inclusion of two dummies on whether someone's father and mother are self-employed.

Again, I end up with very few immigrants who experienced hyperinflation in the sample that imposes a ten-year window between the years of last hyperinflation experience and immigration. Hence, I do not show results considering this sample. Table V.4 reports the results.

Notice that, as expected, a self-employed father or mother has a strong effect on the probability of being self-employed. However, the inclusion of this information does not alter much the marginal effects of experience of hyperinflation. In particular, whenever this estimated effect is significant, it remains significant although a bit smaller. Similarly, whenever this effect is insignificant, it remains insignificant.

These results suggest that the omission of parents' occupational choice is not biasing much my findings. 


\section{V.3 Deep recessions}

Hyperinflation episodes are usually associated with deep recessions. In principle, the driving force of my results could be the experience of deep recessions rather than of hyperinflation episodes. In order to deal with this criticism, I build two measures of exposure to recessions and include them as covariates in the main regressions.

Growth rates per country are calculated using data on GDP from the dataset compiled by Reinhardt \& Rogoff (2009). Once I identify the years each country were in a deep recession, I can follow the same procedure described above to measure exposure to deep recessions. As some information on GDP is missing for some countries, I further exclude individuals for whom the complete record of growth experienced is not available. Hence, the sample considered in this section is smaller than the one used in Section 4.

The first definition of recession follows Giuliano \& Spilimbergo (2009). I say a country in a given year is in a deep recession if its growth rate is less than or equal to the fifth percentile of the growth rate in the sample, which is five percent negative.

The second definition deals with the concern that hyperinflation would be more persistent than the aforementioned definition of recession. Indeed, shocks in GDP are usually followed by a reversion toward the trend. Hence, a negative GDP growth followed by a positive one does not necessarily mean that the recession is over. Thus, I say a country in a given year is in a deep recession if the average GDP growth rate between such year and the two prior years is negative. Notice that this second definition tends to capture the persistence of deep recessions.

Results are shown in Table V.5 for the first definition, and Table V.6 for the second definition. Notice that, despite the smaller sample, results considering only exposure to hyperinflation episodes are similar to those reported in Table IV.1.

Consider the unrestricted sample. In the absence of exposure to hyperinflation episodes, exposure to deep recessions affects positively and, except for one case, significantly the probability of being self-employed. However, the marginal effects are always smaller than their counterparts for hyperinflation experiences. Once I add both types of experiences, exposure to deep recessions ceases to be significant according to the first definition, but remains significant according to the second definition. Importantly, the marginal effects of exposure to hyperinflation episodes remain significant in all cases. Moreover, these effects are always larger than those of exposure to deep recessions. Similar 
conclusions are reached once we exclude individuals who immigrated at least five and ten years after their last hyperinflation experience.

These results suggest that the driving force behind the estimated marginal effects is hyperinflation itself rather than a bad economic environment.

\section{V.4 Wars}

Many hyperinflation episodes are attached to wars. ${ }^{1}$ Thus, it could be argued that the experience of war can have impacts over individuals' occupational choices. Consequently, the previous results attributed to hyperinflation could be biased once the effect of war itself is not accounted for.

Hence, in order to deal with this concern, I employ a dummy which indicates whether the individual experienced a war. However, it is unlikely that minor armed events, which lasted for small periods of time, would have an impact on individuals' choices. Hence, I only consider events to be wars when they lasted for at least a year and involved some sort of territorial occupation or destruction. ${ }^{2}$

Results are presented in table V.7.

The inclusion of the dummy indicating experience of war barely changes the estimated marginal effect of hyperinflation on self-employment across

${ }^{1}$ The following cases, as described in Table II.1: Angola in the 1990s, Austria, China, Finland, Germany, Greece, Hungary, Italy, Japan, Korea, Nicaragua, Philippines, Poland in the 1920s and Turkey in the 1910s.

${ }^{2}$ In the final sample, the following episodes were considered to be wars: Algeria (war of independence between 1954 and 1962), Austria (World War I (WWI) between 1914 and 1918 and World War II (WWII) between 1939 and 1945), Belgium (WWI between 1914 and 1918 and WWII between 1939 and 1945), Bolivia (Chaco War between 1932 and 1935), Myanmar (WWII between 1942 and 1945), China (Civil War and WWII between 1927 and 1950), Colombia (Civil War between 1948 and 1958), Denmark (WWII between 1940 and 1945), Egypt (WWII in 1941 and 1942), El Salvador (Civil War between 1979 and 1992), United Kingdom (WWII between 1939 and 1945), Finland (Civil War in 1918 and WWII between 1939 and 1945), France (WWI between 1914 and 1918 and WWII between 1939 and 1945), Germany (WWI between 1914 and 1918 and WWII between 1939 and 1945), Greece (Balkan Wars, WWI and Greco-Turkish War from 1912 to 1922 and WWII and Civil War between 1939 and 1949), Guatemala (Civil War from 1960 to 1996), Hungary (WWI between 1914 and 1918 and WWII between 1939 and 1945), Indonesia (WWII and National Revolution between 1942 and 1950), Ireland (War of Independence form 1919 to 1921), Italy (WWI between 1914 and 1918 and WWII between 1939 and 1945), Japan (Sino-Japanese War and WWII from 1937 to 1945), Korea (Korean War from 1950 to 1953), Malaysia (WWII from 1942 to 1945), Mexico (Mexican Revolution between 1910 and 1920 and Cristero War from 1926 to 1929), Netherlands (WWI between 1914 and 1918 and WWII between 1939 and 1945), Nicaragua (Civil War from 1961 to 1990), Nigeria (Civil War between 1967 and 1970), Norway (WWII between 1940 and 1945), Paraguay (Chaco War between 1932 and 1935), Philippines (WWII between 1942 and 1945), Poland (WWI and Polish-Ukrainian War between 1914 and 1922 and WWII from 1939 to 1945), Romania (Balkan Wars and WWI between 1912 and 1918 and WWII from 1939 to 1945), Singapore (WWII from 1942 to 1945), Spain (Civil War between 1936 and 1939), Thailand (WWII from 1942 to 1945), Turkey (Balkan Wars, Italo-Turkish War, WWI and War of Independence between 1912 and 1922) and Zimbabwe (Rhodesian Bush War from 1967 to 1979). 
all specifications and criteria of hyperinflation. Furthermore, the effect of experiencing a war is not significant at any usual level in all but one case, the non-restricted sample under the criterion of an annual inflation of at least $100 \%$.

These findings indicate that it is neither the experience of war nor the hyperinflation episodes caused by it that are driving the results.

\section{V.5 Propensity Score Results}

This section presents the results of the propensity score matching approach. The treatment effect of interest is whether an individual lived hyperinflation. Average treatment effects (ATE) are presented in table V.8, which is analogous to table IV.1.

First, noticee that the numbers of observations in each regression are smaller than the ones in table IV.1. This is because many observations are dropped when the propensity score is estimated. In particular, all immigrants from countries which did not have hyperinflation episodes (e.g. Canada) are excluded, as the dummy for each one of these countries would predict failure perfectly.

Furthermore, the quantities here presented are not comparable to the previous ones. While previous tables presented marginal effects of exposure to hyperinflation, table V.8 presents ATEs concerning such experience. This is because, as noted in table II.3, the average experience of hyperinflation for those who were exposed is around 3 (2) years under the criterion of $100 \%$ $(500 \%)$.

Given these issues, it is reassuring that all results present a positive ATE of hyperinflation on the probability of being self-employed instead of wageearner. This strenghtens the previous findings of a positive marginal effect of hyperinflation. 
Table V.4: Hyperinflation, Self-Employment and Self-Employed Parents

\begin{tabular}{|c|c|c|c|c|}
\hline & \multicolumn{4}{|c|}{ Hyperinflation of $100 \%$ per year } \\
\hline & \multicolumn{4}{|c|}{ Years between last hyperinflation and immigration } \\
\hline & \multicolumn{2}{|c|}{ No restrictions } & \multicolumn{2}{|c|}{ More than 5} \\
\hline hyperinflation & $\begin{array}{c}0.00325^{* * *} \\
(0.00103)\end{array}$ & $\begin{array}{c}0.00277^{* * *} \\
(0.000941)\end{array}$ & $\begin{array}{c}0.00722^{* * *} \\
(0.00174)\end{array}$ & $\begin{array}{c}0.00618^{* * *} \\
(0.00152)\end{array}$ \\
\hline father self-employed & & $\begin{array}{c}0.0395^{* * *} \\
(0.00393)\end{array}$ & & $\begin{array}{c}0.0400 * * * \\
(0.00575)\end{array}$ \\
\hline mother self-employed & & $\begin{array}{c}0.0424^{* * *} \\
(0.00468)\end{array}$ & & $\begin{array}{c}0.0498^{* * * *} \\
(0.00686)\end{array}$ \\
\hline No. of observations & & & & \\
\hline$\%$ that experienced hyperinflation & 33. & $7 \%$ & 20. & \\
\hline
\end{tabular}

\begin{tabular}{|c|c|c|c|c|}
\hline \multirow[b]{4}{*}{ hyperinflation } & \multicolumn{4}{|c|}{ Hyperinflation of $500 \%$ per year } \\
\hline & \multicolumn{4}{|c|}{ Years between last hyperinflation and immigration } \\
\hline & \multicolumn{2}{|c|}{ No restrictions } & \multicolumn{2}{|c|}{ More than 5} \\
\hline & $\begin{array}{c}0.00209 \\
(0.00226)\end{array}$ & $\begin{array}{c}0.00164 \\
(0.00210)\end{array}$ & $0.00891^{* *}$ & $0.00703^{* *}$ \\
\hline \multirow{2}{*}{ father self-employed } & & $0.0317^{* * *}$ & & $0.0322^{* * *}$ \\
\hline & & $(0.00421)$ & & $(0.00550)$ \\
\hline \multirow[t]{2}{*}{ mother self-employed } & & $0.0383^{* * *}$ & & $0.0457^{* * *}$ \\
\hline & & $(0.00522)$ & & $(0.00725)$ \\
\hline No. of observations & \multicolumn{2}{|c|}{21,605} & \multicolumn{2}{|c|}{12,633} \\
\hline$\%$ that experienced hyperinflation & \multicolumn{2}{|c|}{$6.72 \%$} & \multicolumn{2}{|c|}{$2.59 \%$} \\
\hline
\end{tabular}

Notes: All specifications include a constant and the following covariates: financial income, and dummies for: years passed since immigration, metropolitan area, relationship to the household head, age, sex, race, marital status, country of birth, educational attainment and houseownership. Robust standard errors in parentheses account for clustering at the country of birth and year of immigration.

*** Significant at the 1 percent level.

**Significant at the 5 percent level.

*Significant at the 10 percent level. 


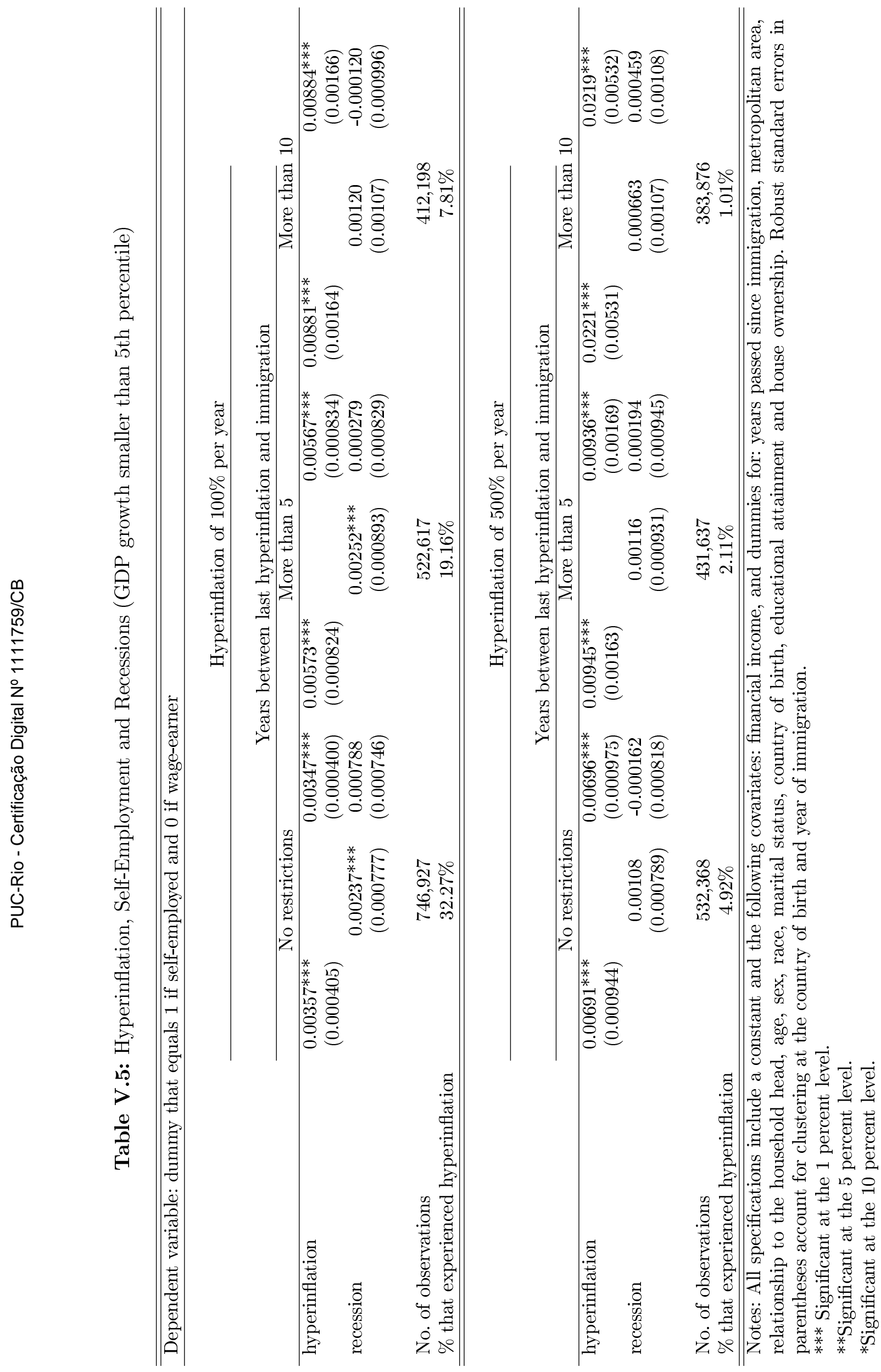




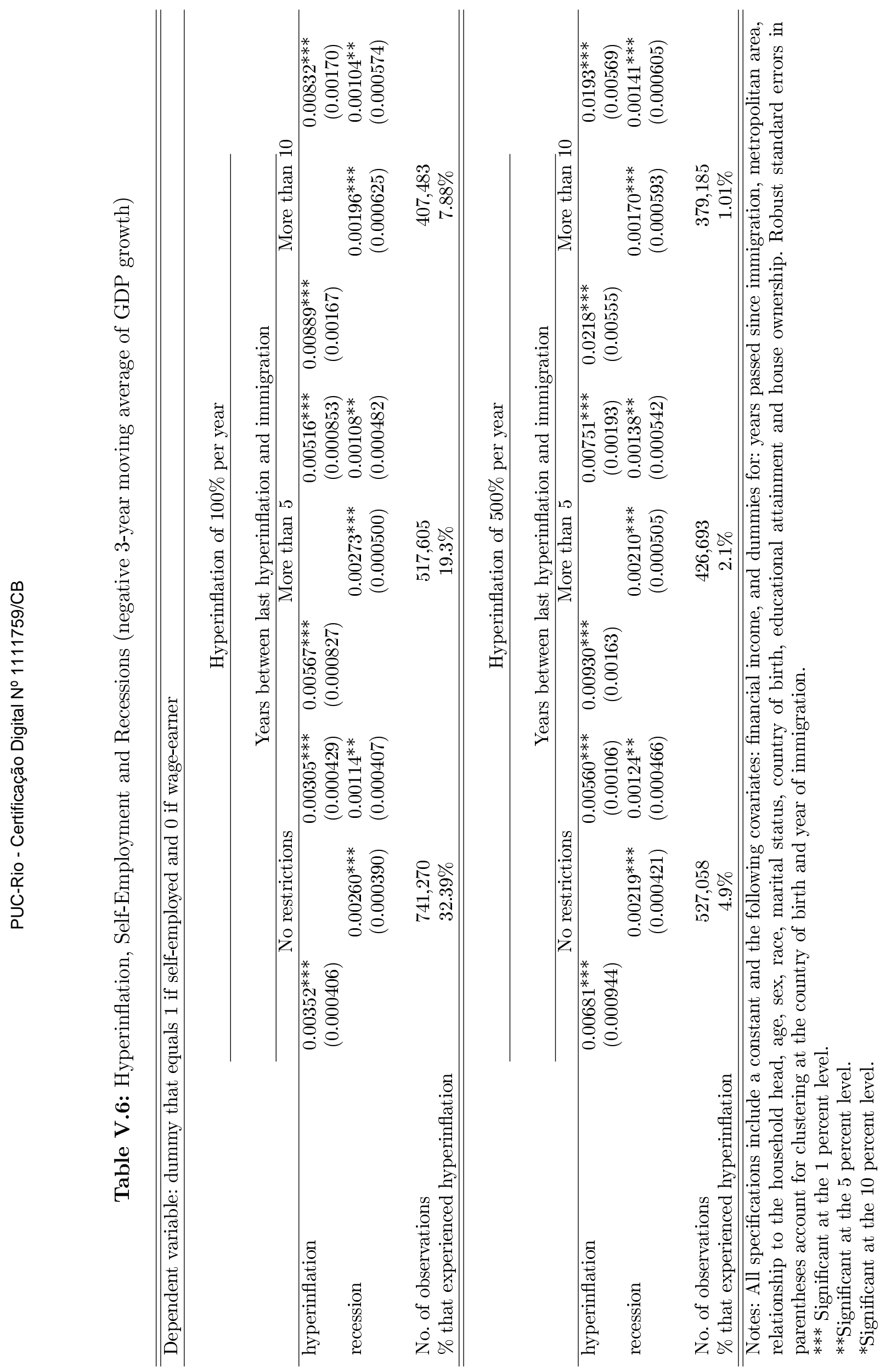




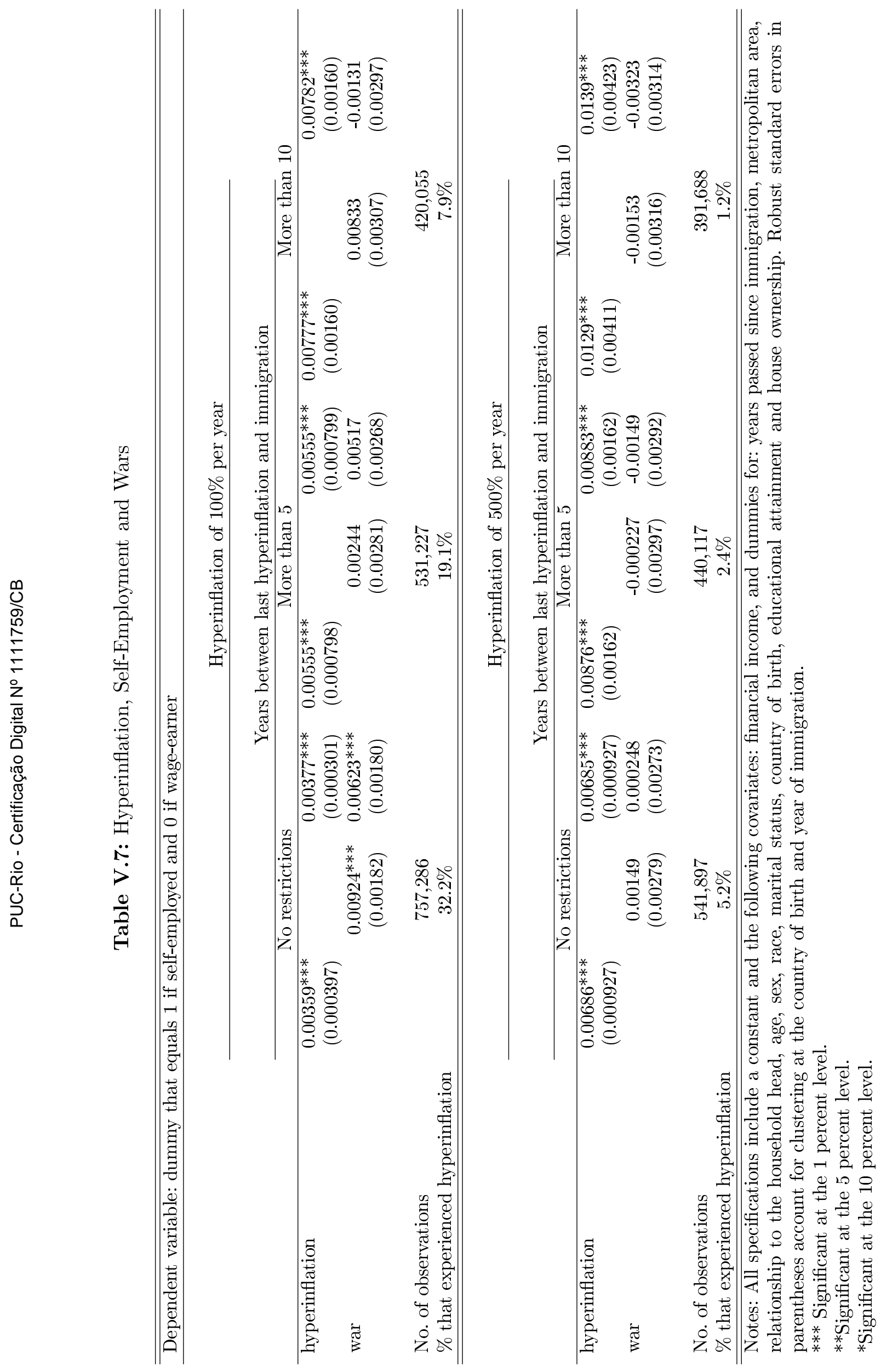


Table V.8: Average Treatment Effect of Hyperinflation on Self-Employment

\begin{tabular}{|c|c|c|c|}
\hline \multicolumn{4}{|c|}{ Dependent variable: dummy that equals 1 if self-employed and 0 if wage-earner } \\
\hline & \multicolumn{3}{|c|}{ Hyperinflation of $100 \%$ per year } \\
\hline & \multicolumn{3}{|c|}{ Years between last hyperinflation and immigration } \\
\hline & No restrictions & More than 5 & More than 10 \\
\hline ATE & $\begin{array}{c}0.0181 \\
(0.0126)\end{array}$ & $\begin{array}{c}0.0598^{* * *} \\
(0.0110)\end{array}$ & $\begin{array}{c}0.0847 \\
(0.0672)\end{array}$ \\
\hline \multirow[t]{4}{*}{$\%$ that experienced hyperinflation } & $\begin{array}{c}524,499 \\
46.5 \%\end{array}$ & $\begin{array}{c}283,449 \\
35.8 \%\end{array}$ & $\begin{array}{c}184,641 \\
18.0 \%\end{array}$ \\
\hline & \multicolumn{3}{|c|}{ Hyperinflation of $500 \%$ per year } \\
\hline & \multicolumn{3}{|c|}{ Years between last hyperinflation and immigration } \\
\hline & No restrictions & More than 5 & More than 10 \\
\hline ATE & $\begin{array}{l}0.0362^{*} \\
(0.0203)\end{array}$ & $\begin{array}{l}0.0299^{*} \\
(0.0169)\end{array}$ & $\begin{array}{c}0.0584 \\
(0.0424)\end{array}$ \\
\hline $\begin{array}{l}\text { No. of observations } \\
\% \text { that experienced hyperinflation }\end{array}$ & $\begin{array}{c}129,147 \\
5.2 \%\end{array}$ & $\begin{array}{c}66,434 \\
2.4 \%\end{array}$ & $\begin{array}{l}47,032 \\
1.2 \%\end{array}$ \\
\hline
\end{tabular}

Notes: Propensity scores were estimated using a constant and the following covariates: financial income, and dummies for: years passed since immigration, metropolitan area, relationship to the household head, age, sex, race, marital status, country of birth, educational attainment and house ownership. Robust standard errors in parentheses account for clustering at the country of birth and year of immigration

***Significant at the 1 percent level.

** Significant at the 5 percent level.

*Significant at the 10 percent level. 


\section{VI}

\section{Conclusion}

I document a positive effect from hyperinflation experiences to selfemployment. My preferred estimate indicates a marginal effect of 0.87 percentage point on the probability of being self-employed. This figure increases to 1.3 percentage points if I restrict the sample to individuals who were between 18 and 25 years of age, the so-called formative years, at their last hyperinflation experience. These effects are small but non-negligible as the share of self-employed individuals in the sample is 9.4 percent.

These results are in congruence with a growing literature, which has documented that exposure to macroeconomic traumatic events shape beliefs, preferences and economic behavior. See footnote 1 for references.

I conjecture a few explanations for my results. First, self-employed individuals have a more flexible cash flow which is valuable in times of hyperinflation. Second, self-employment might be more attractive as business owners can adjust the price of their products as inflation accelerates. Third, hyperinflation episodes are associated with the emergence of black markets, which may provide incentives for individuals to become an informal selfemployed. Finally, by living during a hyperinflation episode, individuals may develop skills and habits, such as financial literacy, that can be profitably employed in an own business. Notice that these arguments are particularly relevant for those at formative years, during which beliefs and behavior are more susceptible to change. 


\section{Bibliography}

R. K. Q. Akee, D. A. Jaeger and K. Tatsiramos. The persistence of selfemployment across borders: New evidence on legal immigrants to the united states. IZA Discussion Paper No. 3250, 2007.

G. J. Borjas. The self-employment experience of immigrants. Journal of Human Resources, 21(4):485-506, 1986.

P. D. Cagan. The monetary dynamics of hyperinflation. In M. Friedman, editor, Studies in the Quantity Theory of Money, chapter 2, pages 25120. Chicago, Il: University of Chicago Press, 1956.

C. D. Carroll, B.-K. Rhee and C. Rhee. Are there cultural effects on saving? some cross-sectional evidence. Quarterly Journal of Economics, 109(3):685-699, 1994.

T. Dunn and D. Holtz-Eakin. Financial capital, human capital and the transition to self-employment: Evidence from intergenerational links. Journal of Labor Economics, 18(2):282-305, 2000.

D. S. Evans and B. Jovanovic. An estimated model of entrepreneurial choice under liquidity constraints. Journal of Political Economy, 97(4):808-827, 1989.

M. Ehrmann and P. Tzamourani. Memories of high inflation. European Journal of Political Economy, 28(2):174-191, 2012.

R. Fernández. Does culture matter? In M. O. Jackson and A. Bisin, editors, Handbook of Social Economics, Vol. 1A, chapter 11, pages 481-510. The Netherlands: North-Holland, 2011.

R. Fernández and A. Fogli. Culture: An empirical investigation of beliefs, work, and fertility. American Economic Journal: Macroeconomics, 1(1):146-177, 2009.

R. W. Fairlie and B. D. Meyer. Trends in self-employment among white and black men during the twentieth century. Journal of Human Resources, 35(4):643-669, 2000. 
R. W. Fairlie and B. D. Meyer. Ethnic and racial self-employment differences and possible explanations. Journal of Human Resources, 31(4):757-793, 1996.

P. Giuliano and A. Spilimbergo. Growing up in a recession: Beliefs and the macroeconomy. NBER Working Paper No. 15321, 2009.

L. Guiso, P. Sapienza and L. Zingales. The role of social capital in financial development. American Economic Review, 94(3):526-556, 2004.

Y. Georgellis and H. J. Wall. Gender differences in self-employment. American Economic Review, 19(3):321-342, 2005.

E. Hurst and A. Lusardi. Liquidity constraints, household wealth and entrepreneurship. Journal of Political Economy, 112(2):319-347, 2004.

M. Hout and H. Rosen. Self-employment, family background, and race. Journal of Human Resources, 35(4):670-692, 2000.

E. Lazear. Entrepreneurship. Journal of Labor Economics, 23(4):649-680, 2005 .

B. F. Lentz and D. N. Laband. Entrepreneurial success and occupational inheritance among proprietors. Canadian Journal of Economics, 23(3):563-579, 1990.

C. Lombardelli and J. Saleheen. Public expectations of uk inflation. Bank of England Quarterly Bulletin, pages 281-290, Autumn 2003.

U. Malmendier and S. Nagel. Depression babies: Do macroeconomic experiences affect risk taking? Quarterly Journal of Economics, 126(1):373416, 2011.

U. Malmendier and S. Nagel. Learning from inflation experiences. Working Paper, 2012.

R. U. Oyelere and W. Belton. Coming to america: Does having a developed home country matter for self-employment in the united states. American Economic Review Papers and Proceedings, 102(3):538-542, 2012 .

C. Reinhardt and K. Rogoff. This time is different: Eight centuries of financial folly. Princeton University Press, 2009.

A. M. Yuengert. Testing hypotheses of immigrant self-employment. Journal of Human Resources, 30(1):194-204, 1995. 